\title{
Pituitary Hormone Receptor Binding
}

National Cancer Institute

\section{Source}

National Cancer Institute. Pituitary Hormone Receptor Binding. NCI Thesaurus. Code C40528.

A process that involves the binding of any member of the group of pituitary hormones, including growth hormone, thyroid stimulating hormone, adrenocorticotropic hormone, follicle-stimulating hormone, luteinizing hormone and prolactin, to their respective receptors. These interactions are essential for glandular development and homeostasis. 